\title{
Research on Industrial Relation and Group Effect of Pearl River West City Circle
}

\author{
Hongmin Zhang \\ Faculty of Management and Administration \\ Macau University of Technology and Science, MUST \\ Macau, China \\ hmzhang@must.edu.mo
}

\begin{abstract}
In a long period of time, resources can't be shared inside Pearl River West City Circle, fragmented situation made the group hard to form a healthy industrial structure on agglomeration advantage and scale advantage. Based on this, the article measures economy and industry associations inner this group, evaluates group effect of specialization and diversity from 2003-2012, to provide a theoretical reference for future strategy formulation to optimize industrial division and harmonious development.
\end{abstract}

keywords- industrial relationship; group effect; pearl river west city circle.

\section{INTRODUCTION}

PRD has become one of the metropolitan districts with strongest economy, highest marketization and internationalization. In the past three decades, the economic development speed of the Pearl River West is lower than the east coast. However, with the intensive harbor, long coastline, low population density, as well as increasingly developed traffic network, adding up sea-air ports integrated transportation, human capital and good ecotope, It gradually becomes ideal place to transfer capital-technology intensive industry from developed countries. True, a chain should be formed in metropolitan development by cooperation, resources sharing and allocation optimization.

However, inside the Pearl River West City Circle (or PRWCC, for short in later part), each city does things in their own way without advantage complemented for long while. Beneficial industrial structure is hard to form on agglomeration and scale advantage. Based on this, the paper aims to measure economy and industry associations inner PRWCC, evaluate the group effect of specialization and diversity from 2003-2012, to give theoretical reference for future strategy formulation which optimize industrial division and harmonious development.

In past studies, PRWCC always scoping as Zhuhai, Zhongshan, Jiangmen and Foshan. Strictly speaking, Foshan maintains closer tie with Guangzhou on economical and geographic location. Meantime, Macau keeps frequent interaction with neighboring city particularly with Zhuhai. Therefore, in this study, PRWCC will be designated as between the west of Pearl River Estuary and east of Silver Island Lake area, including administrative divisions of Zhuhai, Zhongshan, Jiangmen and Macau Special Administrative Region

\section{RESEARCH METHODS, SELECTION OF INDICATORS, DATA SOURCE}

\section{A. Measurement of economic relation intensity}

Economic links between cities depends on population, economies scale and actual distance, also largely influenced by difference in industrial composition. Based on Newtonian gravity model, the author introduces Krugman index $(\mathrm{K})$ which reflects the composition difference between cities. Since big gap exists in economic development levels inner PRWCC, so here's positive correlation between the economic link and Krugman, Model built as follows:

$R_{i j}=K \frac{\sqrt{P_{i} G_{i} \times P_{j} G_{j}}}{D_{i j}^{2}},\left(K=\sum_{k=1}^{n}\left|S_{i k}-S_{j k}\right|\right)$

Wherein, Rij behalf of Economic Relation Intensity between cities, $P$ represents population size, $G$ on behalf of urban economy scale, Dij represents distance between cities, $\mathrm{Sjk}$ represents economic share of $\mathrm{k}$ industry in city $\mathrm{j}, \mathrm{n}$ is the number of cities in all industrial sectors.

Use experience of LiXuexin (2011) for reference, the paper set non-agricultural population to reflect population size, GDP to reflect economy scale, the shortest inter-city highway mileage to reflect distance between cities.

\section{B. Measurement of industrial isomorphism level}

Industrial isomorphism reflects structural similarity between cities, and it used to be represented by industrial structure similarity coefficient.

$$
S_{i j}=\frac{\sum\left(x_{i n} \times x_{j n}\right)}{\sqrt{\left(\sum x_{i n}^{2}\right)\left(\sum x_{j n}^{2}\right)}}
$$

Wherein, Xn denotes percentage of GDP of N departments in each city, $\mathrm{Sij}$ is regional industrial structure similarity coefficient, $0 \leq \mathrm{Sij} \leq 1$, the higher regional industry isomorphic level, the weaker regional complementarities exist.

C. Measurement of overall effect in specialization and diversity

First, do logarithm transformation on Cobb-Douglas production function, get:

$$
\begin{gathered}
\ln \frac{\mathrm{Y}}{\mathrm{L}}=\ln \mathrm{A}+\alpha \ln \frac{\mathrm{K}}{\mathrm{L}} \\
\beta=1-\alpha
\end{gathered}
$$

Wherein, $\mathrm{Y}$ represents output, $\mathrm{K}$ is capital, L is labor, estimated by least square method can work $\alpha, \beta$ out, and 
technological progress increase rate (GI) and contribution rate of economic growth by technological progress(CI) of PRWCC.

$$
\begin{aligned}
& \mathrm{GI}=\frac{\Delta \mathrm{Y}}{\mathrm{Y}}-\alpha \frac{\Delta \mathrm{K}}{\mathrm{K}}-\beta \frac{\Delta \mathrm{L}}{\mathrm{L}} \\
& \mathrm{CI}=\frac{\Delta \mathrm{Y} / \mathrm{Y}-\left(\alpha^{\Delta \mathrm{K} / \mathrm{K}}+\beta^{\Delta \mathrm{L} / \mathrm{L}}\right)}{\Delta \mathrm{Y} / \mathrm{Y}} * 100 \%
\end{aligned}
$$

Wherein, industrial output value reflects total output, fixed assets original value and current assets annual average balance of total capital investment reflects capital input, number of workers is used to reflect situation of labor input. The data involved in this study mainly comes from the annual statistic yearbook of country, province and city from 2003 to 2012 .

\section{CALCULATION RESULTS AND ANALYSIS}

\section{A. Economic relation intensity}

To facilitate comparison, we respectively calculated relation intensity inner PRWCC (A), inner Pearl River East cities (B), and inner Guangdong province (C) (see table 1), found that:

- Value $\mathrm{A}$ is higher than $\mathrm{C}$, and lower than B. To some extent, it attributes to similar structure inner PRWCC which still focused on labor-intensive industrial except Macau.

- From time series, relation intensity inner PRWCC shows a gradually increasing trend, increasing velocity is faster than the East in large extent to regional integration strategy and operation of Guang-zhu metro.

- For special model of economic development in Macau, it has less relation intensity with rest of PRWCC in primary and secondary industry, and closer relationship in tertiary industry. Meanwhile, since the special historic and cultural factor exist between Macau-Zhongshan and Macau-Jiangmen, the rule of "distant decay" seems doesn't work.

Table 1 Relation Intensity Scale

\begin{tabular}{|l|c|c|c|}
\hline Year & 2003 & 2008 & 2012 \\
\hline A & 3214.1 & 3531.4 & 3920.1 \\
\hline B & 10275.4 & 11395.7 & 12275.3 \\
\hline C & 2827.6 & 3038.2 & 3146.5 \\
\hline
\end{tabular}

Data source: Guangdong statistical yearbook, Guangdong city year book of 2003, 2008, 2012

\section{B. Industrial isomorphism level}

According to three industrial classification criteria, respectively calculates the structure similarity coefficient in secondary and tertiary industry. Found that (Table 2):

- $\quad$ By industrial structural similarity, the coefficient between Zhuhai and Zhongshan reaches the highest point 0.7908, because they treat manufacture of communication and electrical machinery as the two pillar industries which maintain high proportion in whole industry, led to terribly overlap industry construction and fierce competition. While Jiangmen focus on metal production and transportation equipment industry, has obvious fewer overlays with rest of PRWCC. As well as Macau, because the only major industry is garment industry, and output value proportion is small.

- $\quad$ By service structure, coefficient between Zhuhai and Zhongshan up to 0.98 , while respectively less with Jiangmen and Macau, while coefficient with Guangzhou which has developed tertiary industry also simultaneously showing decreasing trend, says that is likely to caused by relatively low development of tertiary industry in PRWCC.

Table 2 Change of industrial structure similarity coefficient in

\begin{tabular}{|c|c|c|c|c|c|c|}
\hline & & & $\begin{array}{l}\text { Zhong } \\
\text { shan }\end{array}$ & $\begin{array}{l}\text { Jiang } \\
\text { men }\end{array}$ & Macau & Guangzho \\
\hline \multirow{6}{*}{$\begin{array}{l}\text { In } \\
\text { Seco } \\
\text {-ndary } \\
\text { Indu } \\
\text {-stry }\end{array}$} & \multirow{2}{*}{$\begin{array}{l}\text { Zhu } \\
\text { hai }\end{array}$} & 2003 & 0.8588 & 0.4934 & 0.4011 & 0.6223 \\
\hline & & 2012 & $0.7908 \downarrow$ & $0.4738 \downarrow$ & $0.4729 \uparrow$ & $0.5020 \downarrow$ \\
\hline & \multirow{2}{*}{$\begin{array}{l}\text { Zhong } \\
\text { shan }\end{array}$} & 2003 & -- & 0.5219 & 0.3964 & 0.6147 \\
\hline & & 2012 & -- & $0.5004 \downarrow$ & $0.4072 \uparrow$ & $0.6123 \downarrow$ \\
\hline & \multirow{2}{*}{$\begin{array}{l}\text { Jiang } \\
\text { men }\end{array}$} & 2003 & -- & -- & 0.3014 & 0.5821 \\
\hline & & 2012 & -- & -- & $0.3119 \uparrow$ & $0.5643 \downarrow$ \\
\hline \multirow{6}{*}{$\begin{array}{l}\text { In } \\
\text { Terti } \\
\text {-ary } \\
\text { Indu } \\
\text {-stry }\end{array}$} & \multirow{2}{*}{$\begin{array}{l}\text { Zhu } \\
\text { hai }\end{array}$} & 2003 & 0.9747 & 0.9305 & 0.7621 & 0.9269 \\
\hline & & 2012 & $0.9805 \uparrow$ & $0.9404 \uparrow$ & $0.7905 \uparrow$ & $0.9130 \downarrow$ \\
\hline & \multirow{2}{*}{$\begin{array}{l}\text { Zhong } \\
\text { shan }\end{array}$} & 2003 & -- & 0.9140 & 0.6541 & 0.8418 \\
\hline & & 2012 & -- & $0.9221 \uparrow$ & $0.6629 \uparrow$ & $0.8447 \uparrow$ \\
\hline & \multirow{2}{*}{$\begin{array}{l}\text { Jiang } \\
\text { men }\end{array}$} & 2003 & -- & -- & 0.6170 & 0.8021 \\
\hline & & 2012 & -- & -- & $0.6332 \uparrow$ & $0.8143 \uparrow$ \\
\hline
\end{tabular}
PRWCC

Data source: from China statistical yearbook and Guangdong provincial economic census data.

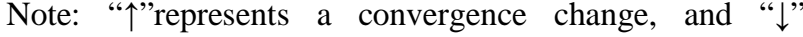
represents a divergence change.

Thus, industrial isomorphic degree is high, while correlation is low, that will directly affects regional industrial structure adjustment and optimization, and constraints the improvement of regional comprehensive competitiveness.

C. Group effect in specialization and diversity

Obtained by the least squares method to estimate the specialization of industrial upgrading and technological progress of model is:

$$
\ln \frac{Y}{L}=0.682+0.594 \ln \frac{K}{L}
$$

In the formula, correlation coefficient between variables $\mathrm{R}=0.636$, shows high positive correlation, with confidence level of $90 \%$, capital elasticity coefficient $(\alpha)$ and labor flexibility coefficient $(\beta)$ valued as follows (Table 3 ):

Table 3 elastic coefficient of production function in PRWCC

\begin{tabular}{|l|l|l|l|l|}
\hline & $\begin{array}{l}\text { Enterprise } \\
\text { unit } \\
\text { number }\end{array}$ & $\mathrm{R}$ & $\alpha$ & $\beta$ \\
\hline Overall industry & 46483 & 0.620 & 0.555 & 0.445 \\
\hline Specialized industry & 28913 & 0.636 & 0.594 & 0.340 \\
\hline Unspecialized industry & 17570 & 0.506 & 0.497 & 0.503 \\
\hline
\end{tabular}

Data source: China statistical yearbook (2003-2012) 
According to the estimation results elasticity coefficient, get corresponding result as average growth rate of technological progress, capital growth, labor growth, technological progress contribution rate (as Table 4), shows that:

Table 4 Industrial technology progress of growth and contribution growth in different industry in both sides of PRD units: \%

\begin{tabular}{|c|c|c|c|c|c|c|c|c|c|}
\hline $\begin{array}{l}\text { Cont } \\
\text { ent }\end{array}$ & $\begin{array}{l}\text { Reg } \\
\text { ion }\end{array}$ & $\begin{array}{l}\text { Yea } \\
\mathrm{r}\end{array}$ & $\mathrm{O}$ & $\mathrm{C}$ & $\mathrm{L}$ & $\mathrm{T}$ & $C^{\prime}$ & $\mathrm{L}^{\prime}$ & $\mathrm{T}^{\prime}$ \\
\hline \multirow{4}{*}{$\begin{array}{l}\text { Speci } \\
\text {-alize } \\
\text { d }\end{array}$} & \multirow{2}{*}{$\begin{array}{l}\text { We } \\
\text { st }\end{array}$} & A & 23 & 22 & 5 & 7 & 61 & 7 & 30 \\
\hline & & B & 49 & 42 & 8 & 18 & 57 & 5 & 37 \\
\hline & \multirow[t]{2}{*}{ East } & A & 16 & 11 & 10 & 5 & 40 & 21 & 33 \\
\hline & & B & 37 & 21 & 19 & 16 & 33 & 21 & 44 \\
\hline \multirow{4}{*}{$\begin{array}{l}\text { Unsp } \\
\text {-ecial } \\
\text {-ized }\end{array}$} & \multirow{2}{*}{$\begin{array}{l}\text { We } \\
\text { st }\end{array}$} & A & 9 & 11 & 5 & 1 & 58 & 29 & 12 \\
\hline & & B & 29 & 24 & 9 & 5 & 55 & 21 & 23 \\
\hline & \multirow[t]{2}{*}{ East } & A & 12 & 9 & 8 & 3 & 61 & 11 & 27 \\
\hline & & B & 25 & 11 & 18 & 6 & 62 & 11 & 26 \\
\hline
\end{tabular}

Data source : Guangdong statistical yearbook of 2003-2012

Note: $\mathrm{O}=$ output value growth rate, $\mathrm{C}=$ capital growth rate, $\mathrm{L}=$ labor growth rate, $\mathrm{T}=$ technology progress growth rate, $\mathrm{C}^{\prime}=$ capital contribution rate, $\mathrm{L}^{\prime}=$ labor contribution rate, T'=technology contribution rate; $A=2003-2012, B=2012$.

- Vertical perspective, technological progress growth rate remains in stable increase in PRWCC, specialized growth rate is greater than both overall level and non-specialized industry, same as technological progress contribution rate;

- Lateral view, technological progress growth rate in PRWCC is higher than Pearl East, while the contribution rate is relatively lower than the latter, for which mostly based on comprehensive influence from historical basis, location and policies differences. With large scale of foreign investment and technology spillover effect, The East reaches visibly higher marketization than PRWCC; the gap on technological progress contribution rate in specialized industry in both sides of Pearl River is lightly more than unspecialized part. PRWCC only stay on medium level in industry diversity. Nevertheless, with deepening of specialization, group economic benefits are gradually up now.

\section{REGIONAL ECONOMIC DEVELOPMENT PROPOSALS}

As a whole, PRWCC has not fundamentally change the "large and complete" state, isn't conductive to form market mechanisms and resource allocation efficiency. From perspective of regional division of labour, inter-regional division and cooperation based on resource endowment will be helpful for implementation of "orderly" and "efficiency".

- Form function complementary modern cities circle: Zhuhai and Macau linkage development become the important tourist city, pivotal ports in southern China;
Zhongshan and Jiangmen become the tourism extended bead, also modern industry and modern agriculture base.

- $\quad$ Form unique structure and property industrial circle. Each city coordinated develops chemical industry, appliances, electronic information, textile, ocean industry and modern agriculture; develop tourism complete set around gaming industry of Macau; strengthen economic relation intensity.

- $\quad$ Form modernized transportation and communication net at home and abroad. Construct international and domestic aviation network by Zhuhai airport and Macau airport linkage; develop port circle that led by Zhuhai port with small port supporting in PRWCC; build road traffic system on Guangzhou-Zhuhai Highway basis; build information mesh networking.

It should be said, after the first round development, the Pearl River East has to face with increased cost, land deficit, water and population constrains, and so on. Radiation effect from Hong Kong becomes more and more weak. At the same time, operation of Guangzhou-Zhuhai metro and construction of HongKong- Zhuhai-Macau Bridge injects new vitality for PRWCC, tourism industry and service will be achieved rapid development.

\section{REFERENCE}

[1] Krugman, Geography and trade, Beijing: Chinese people's University Press, 2000, 23-36

[2] Mao Yanhua, Industrial division, Regional Cooperation, and Economic Transition of HongKong and Macau, Beijing: China Social Sciences press, 2010, 203-217.

[3] Li Jiangtao, Transition and Stride: Regional Competitive Power, Beijing: People's Publishing House, 2011, 25-39.

[4] Li Xuexin, differences comparison between Central Plains city circle and Yangtze river delta city circle, Statistics and Decision, 2012(11).

[5] Maddi Garmendia,Vicente Romero,Jose Maria de UrenaJose, Marfa CoronadoRoger, Vickerman, High-Speed Rail Opportunities around Metropolitan Rigions: Madrid and London, Journal of infrastructure systems 2012.4

[6] Laia Domenech, Hug March, David Sauri. Degrowth initiatives in the urban water sector? A social multi-criteria evaluation of non-conventional water alternatives in Metropolitan Barcelona , Journal of cleaner production, 2013.1. 